\title{
Review
}

\section{Deweyan experimentalism and the problem of method in political philosophy}

\author{
Joshua Forstenzer \\ Routledge, New York, 2019, xiv + 294, pp., \\ ISBN: 978-1138479906
}

Contemporary Political Theory (2022) 21, S179-S181. https://doi.org/10.1057/s41296021-00526-5; published online 4 October 2021

What kind of methods should political theorists use? Political theorists could do ideal theory in the style of John Rawls in which they first identify principles of justice and then apply them to reality. Alternately, they could do empirical political science, or realist political theory, in which they seek to understand institutions, power, and political behavior without the distorting lens of moral judgments. A third approach, and the one that Joshua Forstenzer carefully presents and defends in Deweyan Experimentalism and the Problem of Method in Political Philosophy, is to extract ideals from the current milieu and reconstruct them to address problems facing the community here and now.

Forstenzer presents Dewey's method as a systematic corrective to Rawls while still maintaining that political theory must address injustice in the world. Here are a few of Dewey's correctives to Rawlsian ideal theory:

(1) Rawls prioritizes the activity of philosophers in their armchairs rather than the concerns of actual democratic citizens. Dewey, on the contrary, maintains that political theorists must start from concrete political, social, and cultural problems facing the public and judge success or failure by whether their ideas help ameliorate these problems.

(2) Rawls, according to Forstenzer, lacks a theory of transition, that is, an account of how citizens may use philosophic notions of justice to change society here and now. Dewey, as a proponent of the scientific method, thinks that political theorists need to start, proceed, and end closer to lived reality. Dewey's theory of transition thus involves studying the problems that afflict the community, investigating whether other communities have solved these problems, generating hypotheses about how to address the problems, debating the plan of action with fellow citizens, implementing the plan, and attending to consequences to change course if need be.

(c) 2021 The Author(s), under exclusive licence to Springer Nature Limited. 1470-8914 Contemporary Political Theory Vol. 21, S4, S179-S181

www.palgrave.com/journals 
(3) Rawls, as a philosopher, was more like an architect than an engineer, envisioning a just society, but letting other people figure out how to build it. Forstenzer's Dewey attends to power and how force is sometimes necessary to change the environment and not just people's hearts: 'To think otherwise is to suppose that flowers can be raised in a desert or motor cars run in a jungle' (Dewey, cited on p. 224).

For me, the finest formulations in the book are when Forstenzer describes the role of Deweyan political theorists as citizens who have a certain toolbox that they can use to help other people. Theorists are not 'discovers of abstract truths' unknown to their fellow citizens; instead, they are democratic citizens, like everyone else, trying to address problems such as climate change and declining civic trust. Political theorists are like 'competent chairpersons in the ongoing decision-making process that is cultural renewal'. That is a great way to describe how political theorists often draw on specialists - in the natural sciences, in foreign languages, in other literatures, and so forth-to propose fixes to problems that may have escaped other people working in their silos. 'They thus ought to see themselves as translators of abstract knowledge and ideas into more concrete terminology, as well as dreamers whose powerful imaginations might enable them to envision new ways to solve collective problems' (p. 233). Even if you believe, like Dewey and Forstenzer, in the accomplishments of modern science, you can still see a role for political theory as building bridges between academia and the world, between the natural sciences and the social sciences, and between presentday reality and a better world on the horizon.

Here are two things that I would have liked to see in the book, or that Forstenzer may want to do in the next stage of his career.

First, the book alludes to 'Dewey's prolific engagement with matters of public interest' (p. 3), but the book never goes into detail about how Dewey himself used his method in his activism on education, civil rights, civil liberties, teacher unions, or higher education. In his philosophy, Dewey could sometimes use ethereal language of the public, free use of collective intelligence, communal problems, and so forth. Learning about his concrete interventions in the world could illustrate what Dewey himself understood by those terms. Eric Thomas Weber (2021) has recently edited a collection of Dewey's public-facing work. Deweyan political theorists could read his more abstract and more engaged work in light of each other and his biography. What are the lessons for contemporary education scholaractivists, say, in how Dewey participated in debates in his own time about vocational education? What could democratic political theorists do today in the face of neoliberal demands that schools produce workers and raise revenues for universities, companies, and society at large? 
Second, the book misses an opportunity to do the kind of engaged political theorizing it recommends. The final chapter of the book describes political philosophers who address real-world problems, but the book itself does not scrutinize one real-world problem, offer a suggestion about how to address it, consider how to implement this suggestion, and so forth. To my mind, the book could have cut some of the summary of Dewey's philosophy, Rawls's philosophy, and Robert Talisses' critique of Dewey for failing to understand the fact of reasonable pluralism and instead gone into more detail about how democrats could address a concrete problem in the world right now. Just as you discover things when dancing that you do not appreciate as a spectator, I think that democratic political theorists gain insights about methods when they enter the fray of public debates about social, political, and cultural issues.

Many political and social scientists think that morality is something handled by academics in another building on campus. Professional philosophers can sometimes do hair-splitting conceptual work on issues far removed from popular concerns. Dewey's method is to insist that political theorists live and work at the intersection of intellectual life and the real world. Forstenzer has done a real service in reviving Dewey's conception of method for the present generation of political theorists.

\section{Reference}

Weber, E.T. (2021) America's Public Philosopher: Essays on Social Justice, Economics, Education, and the Future of Democracy. Columbia University Press.

Publisher's Note Springer Nature remains neutral with regard to jurisdictional claims in published maps and institutional affiliations.

Nicholas Tampio

Fordham University, Bronx, NY 10458, USA tampio@fordham.edu 